\title{
Analysis of dynamic characteristics of human serum albumin binding site residues and its effect on azapropazone binding to HSA
}

\author{
Amirhossein Saeinia ${ }^{1}$, Seyed Mahdi Alavi², Elmira Vanaki², and Mohammad Nazarnejad ${ }^{1}$ \\ ${ }^{1}$ Azad University \\ ${ }^{2}$ NIGEB
}

June 1, 2021

\begin{abstract}
Background: Human serum albumin (HSA) is the most abundant protein in the circulatory system compared to other proteins and has been analyzed in a wide range of studies. In this research, molecular dynamics and docking of HSA with azapropazone have been simulated. Methods: The three-dimensional structure of human serum albumin was obtained to simulate molecular dynamics from RCSB. GROMACS was used for molecular dynamic simulations and received 30 frames. Autodock vina was used for docking between HSA and Azapropazone. Results: Based on the obtained results, the residues of Sudlow I junction have structural changes according to their chemical properties. Conclusion: In this study, a new method has been used on HSA compared to previous studies that can be used in drug design research. Understanding the structural and behavioral characteristics of HSA binding site can be a great help in drug design because structural changes in binding amino acids affect drug binding
\end{abstract}

\section{Hosted file}

HSA.docx available at https://authorea.com/users/417176/articles/524361-analysis-ofdynamic-characteristics-of-human-serum-albumin-binding-site-residues-and-its-effecton-azapropazone-binding-to-hsa 